\title{
Facebook as a Museum Content Sounding Board
}

\author{
Ileana Kurtović, Željka Miklošević \\ Department of Information and Communication Sciences \\ University of Zagreb Faculty of Humanities and Social Sciences \\ Ivana Lučića 3, Zagreb, Croatia \\ ilkurtovi@gmail.com, zmiklose@ffzg.hr
}

\section{Summary}

This paper gives an analysis of the ways in which three US museums with longstanding presence on social media and high online audience engagement use Facebook as a platform for distributing information about their programmes and topics relevant for their collections. Information technology influences the work environment in heritage institutions, changes their organization and calls for new responsibilities in the process of shaping online content in order to meet the needs of online users. The primary goal of the paper is therefore to reveal these activities and detect professional trends that can be of use in further research and help define online strategies for museums in general.

Keywords: Facebook, museums, communication, online information resources

\section{Introduction}

The development of new media has changed the way we find and exchange information, learn, establish and maintain relationships, or communicate in general. In order to follow these trends museums need to redefine and redesign their traditional cultural services into new forms of resources which engage audiences via new technologies. Online information resources play today a major role in determining museums' mission statements and communication strategies. Marty's research on the use of museum online or onsite information resources $^{1}$ shows that among 1065 participants $75.6 \%$ agreed $^{2}$ that museum websites should take advantage of the online environment to present unique experiences that cannot be duplicated in museums. In addition, 83.9\% agreed that their needs and expectations of information on museum websites are different from their needs and expectations when visiting museums. Social media sites, for example, offer various ways of improving museum marketing and commu-

\footnotetext{
${ }^{1}$ Marty, Paul F. Museum websites and museum visitors: digital museum resources and their use. // Museum Management and Curatorship. 23 (2008), 1; 81-99.

2 The percentages here represent both "agree" and "strongly agree" answers to the proposed statements.
} 
nication practices ${ }^{3}$ and establish physical or virtual relationships with their audiences. They are used by museums for "pushing" information, either to promote the institution and its programmes ${ }^{4}$, or to distribute knowledge in the subject areas about which they build their collections. The former practices belong to what Kidd calls the marketing framework of social media use ${ }^{5}$. The analysis of three US museums' Facebook pages presented in this paper aims to illustrate how the selected museums use this particular social media site as a sort of sounding board for numerous institutional activities and information resources.

\section{Research Questions and Methods}

The museums selected for the study include New York's Museum of Modern Art, Museum of Science and Industry Chicago and the National Museum of American History. The selection is based on Edson and Dean's typology of museums according to collection type (art, social history and science) ${ }^{6}$, on the number of Facebook likes provided by Museum Analytics ${ }^{7}$ and the country of origin - the US as the country whose museums, in addition to UK ones, are leading institutions in social media use. ${ }^{8}$ Their high social media presence and online value creation makes them representatives of online practices whose analysis can help in forming digital communication strategies for other museums. The research questions are therefore the following:

- What type of content do museums deliver through Facebook?

- What is the ratio between posts related to online and onsite content?

- What is the difference in museum online contents among different types of museums?

- What is the relationship between online content and engagement of Facebook users?

The first phase of the research included an analysis of posts published on the museums' Facebook pages from January to December 2014 and their categorization according to whether the information they contain relate to onsite programmes or online content. The formulation of categories and sub-categories followed a pilot study period during which the categories were tested and modified.

\footnotetext{
${ }^{3}$ Kelly, L. How Web 2.0 is Changing the Nature of Museum Work. // Curator. 53 (2010), 4; 405-410.

4 Dudareva, Natalia. Museums in Social Media. // Museums and the Web 2013 / Proctor, N.; Cherr, R. (ed.). Silver Spring, MD: Museums and the Web, 2014.

URL:http://mwf2014.museumsandtheweb.com/paper/museums-in-social-media/ (15.09.2014)

${ }_{5}$ Kidd, Jenny. Enacting engagement online: framing social media use for the museum. // Information Technology \& People. 24 (2011), 1; 64-77.

${ }^{6}$ Edson, Gary; Dean, David. The Handbook for Museums. London, New York: Routledge, 1996

${ }^{7}$ Museum Analytics.URL: http://www.museum-analytics.org/museums/ (10.03.2015.)

8 Padilla-Meléndez, Antonio; Águila-Obra, Ana Rosa del. Web and social media usage by museums: Online value creation. // International Journal of Information Management. 33 (2013); 892-898.
} 
Posts related to onsite programmes include the following sub-categories:

1. Programmes in the museum (information related to current and upcoming events, workshops, lectures, special guided tours, film screenings, etc.)

2. Programmes in the museum shop (book and product presentations)

3. Programmes in other sites (events at other institutions)

Post related to online content include the following sub-categories:

1. Posts with links to museum sites ${ }^{9}$ (museum collection with interpretation of objects, museum blogs with interpretation of objects, group of objects or exhibitions, blog wrote in collaboration with museum curators, museum web pages with games or educational resources)

2. Posts with links to non-museum sites (information published on news portals, online magazines, websites of other museums)

3. Posts with no links (information posted only on Facebook such as videos and photos with short introductory text)

The second phase of the research included a quantitative analysis of 1522 posts in the SPSS 17.0. A frequency table was used to describe the sample. The data were also evaluated by bivariate correlation analysis and the results displayed as pie and column charts in Tables $1-6$. Considering the topic of the paper, the results shown here are more focused on online museum content and users' responses to it.

Table 1. Ratio between onsite programmes and online content

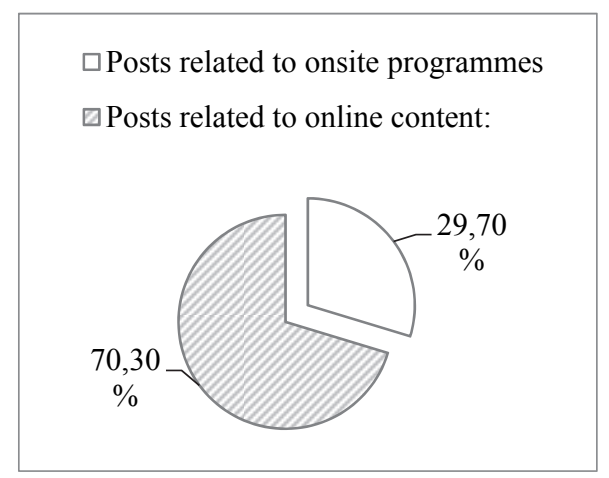

Table 2. Percentages of posts in three subcategories of online content

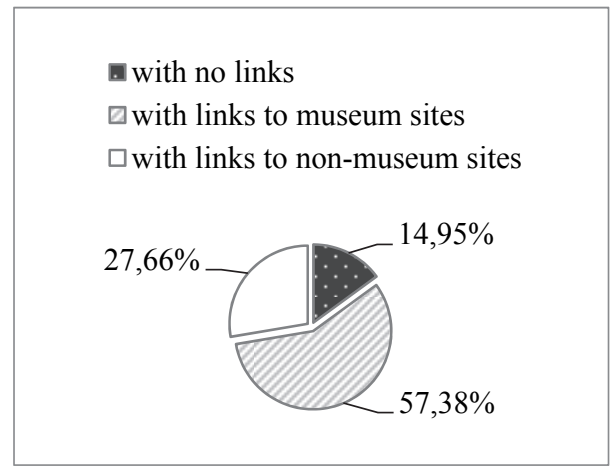

\footnotetext{
${ }^{9}$ This sub-category does not include posts with links to the museum website content that solely provides short information about duration, participants, and venue of events or give a short description of an event and provide no interpretation of museum objects, exhibits or the like.
} 
Table 3. Types of post related to online content on each museum's Facebook page

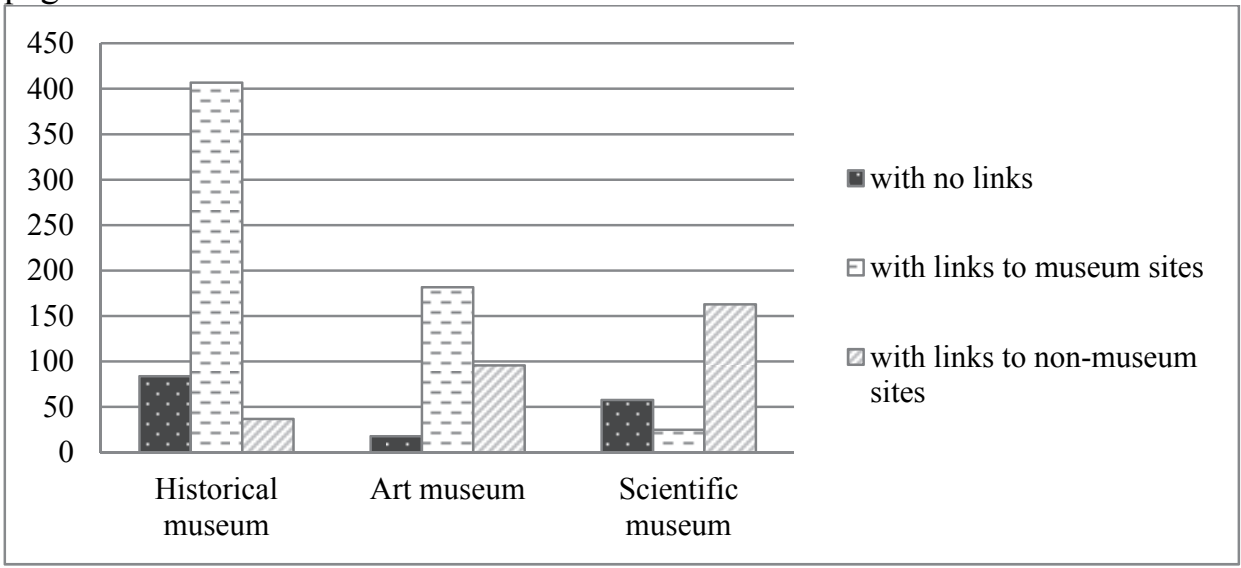

Table 4. Online content and number of likes

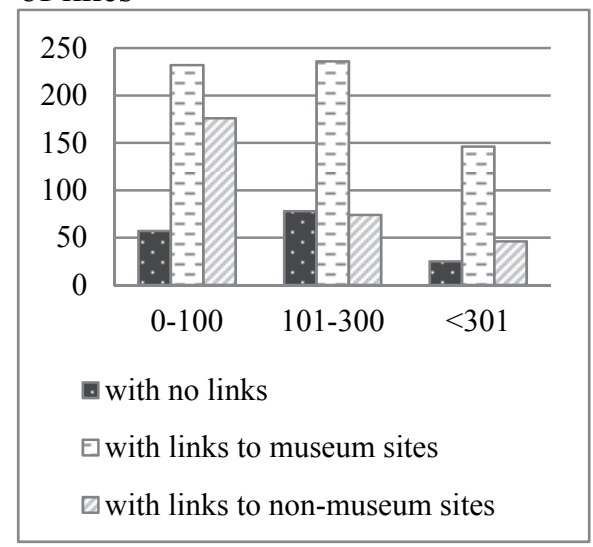

Table 5. Online content and number of comments

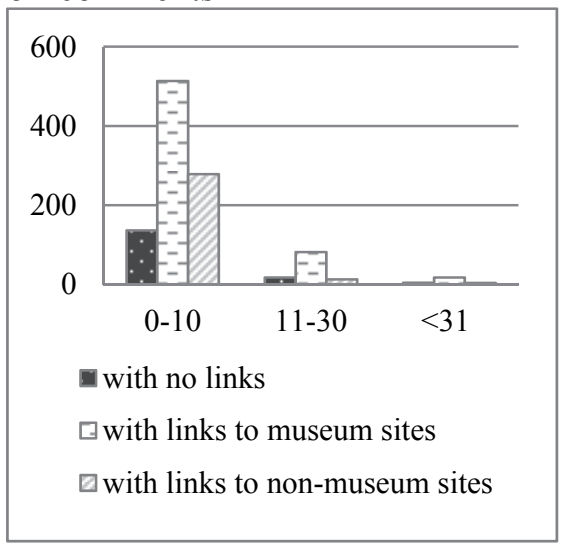

Table 6. Online content and number of shares

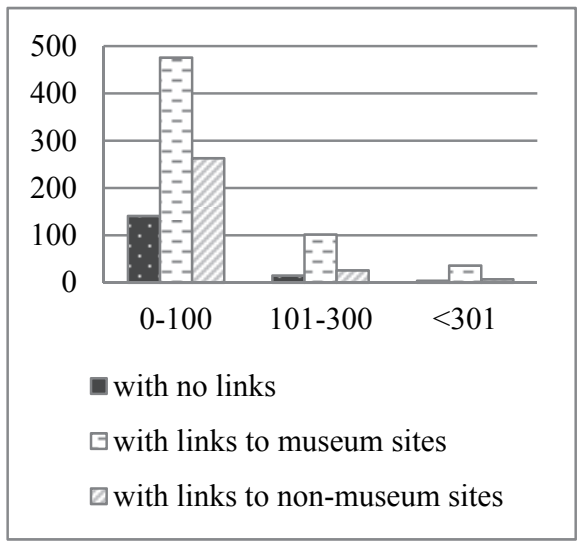




\section{Discussion and conclusion}

The results show that a considerable number of posts contain information related to online content (Table 1) proving that these three museums have moved away from using Facebook to promote the "face" of the institution through their onsite programmes. From the total number of posts to online content, the biggest number or $57.38 \%$ relates to contents on museum websites (Table 2). These resources can inform and prepare people for the physical visit, reinforce the experience after the visit, or create independent, online experiences that can be utterly different from onsite programmes. When examined individually (Table 3), the museums show a difference in the way they shape and contextualize different information. The Science and Industry Museum Chicago publish the biggest number of posts with links to non-museum sites such as online science magazines and portals that deal with science-related topics in general. By doing that, it provides much larger context for topics it deals with and objects it collects. This sort of activity supports the museum communication strategy that is mostly grounded in science phenomena more than objects that witness scientific developments. Conversely, MoMA's posts are more related to collections and exhibitions whose interpretation is given on the museum website. Its online content is more than in other two museums tied to the collection, which is especially evident in Facebook posts directly linked to the online catalogue of objects. Facebook posts of the National Museum of American History are largely dependent on the museum website where curators and educators develop interpretive packages for users. Very small number of links to other online sites may be explained by a wide range of approaches, views and interpretations of historical topics and the reluctance of the museum to refer to some of them. Further elaboration is needed on the relationship between the museums' subject area and digital resource formation.

The statistical analysis of likes, comments and shares, in relation to online content (Tables $4-6$ ) shows that information developed on museums' web sites and distributed through Facebook engage users the most. On the one hand, it reflects the highest number of posts with links to online museum sites, but, on the other hand, it can be related to a specific manner of delivering information by museum professionals. However, better understanding of the relationship between digital content and user engagement requires a mixed-method research which could show correspondence between types of content and types and frequency of responses.

\section{References}

Dudareva, Natalia. Museums in Social Media. // Museums and the Web 2013 / Proctor, N.; Cherr, R. (ed.). Silver Spring, MD: Museums and the Web, 2014

URL:http://mwf2014.museumsandtheweb.com/paper/museums-in-social-media/ (15.09.2014)

Edson, Gary; Dean, David. The Handbook for Museums. London, New York: Routledge, 1996

Holdgaard, N. The Use of Social Media in the Danish Museum Landscape. // Museums and the Web 2011: Proceedings / Trant, J.; Bearman, D. (ed.). Toronto: Archives \& Museum Infor- 
matics URL: http://conference.archimuse.com/mw2011/papers/the_use_of_social_media_in the_danish_museum (24.05 2012.)

Kelly, $\overline{\text { L. How }}{ }^{-}$Web 2.0 is Changing the Nature of Museum Work. // Curator. 53 (2010), 4; 405-410

Kidd, Jenny. Enacting engagement online: framing social media use for the museum. // Information Technology \& People. 24 (2011), 1; 64-77

Marty, Paul F. Museum websites and museum visitors: digital museum resources and their use. // Museum Management and Curatorship. 23 (2008), 1; 81-99

Museum Analytics.URL: http://www.museum-analytics.org/museums/ (10.03.2015.)

Padilla-Meléndez, Antonio; Águila-Obra, Ana Rosa del. Web and social media usage by museums: Online value creation. // International Journal of Information Management. 33 (2013); 892-898 